\title{
A COMMENTARY ON THE SELECTION OF JUDGES IN CHINA: FROM THE PERSPECTIVE OF JUDICIAL PROFESSIONALIZATION
}

\author{
Zhiwen Yang *
}

\begin{abstract}
Judge Selection is a key part of China's judicial Reform, because it is concerned with the level of judicial personnel and the quality of dispute resolution, and further related to China's march toward rule of law. This paper reviews the current situation of China's judge selection in terms of the entrance exam for judges, the qualification and selection of judges, and the training for judges. Then the paper analyzes the problems that arise in China's judge selection from the perspectives of the basic principles of modern legal profession, the basic characteristics of modern judiciary, and the trend of worldwide judge selection. Furthermore, the paper proposes four pieces of advice on improving China's professionalization of judge selection.
\end{abstract}

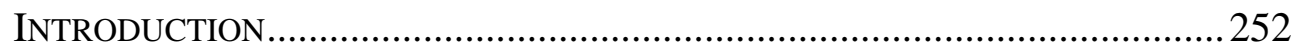

I. CurRent Situation of ChinA’s JudGe SELECTION ............................ 253

A. The Entrance Exam for Judges......................................... 253

B. The Qualification and Selection of Judges ........................... 254

C. The Training for Judges ..................................................... 256

II. The Problems of ChinA's JudGe SELECTION.................................... 258

A. Not Fully Respect the Basic Principle of Modern Legal

Profession ........................................................................................... 258

B. Not Comprehensively Manifest the Basic Characteristics of

Modern Judiciary.

C. Not Completely Present the Trend of Worldwide Judge Selection.

III. The AdVICE ON CHINA's PROFESSIONALIZATION OF JUDGE SELECTION

A. To Establish a Combined System of Judge Selection ............... 262

B. $\quad$ To Explore Multiple Ways of Judge Selection .......................... 263

C. $\quad$ To Build a Comprehensive Training System ............................ 265

D. To Promote the Reform on the Formation of Judicial Personnel ..

\footnotetext{
${ }^{*}$ Zhiwen Yang, Assistant Professor at the Institute of Social Sciences of the East China University of Political Science and Law, China. Research fields: Jurisprudence, Judicial Systems and Legal Profession.
} 


\section{INTRODUCTION}

Since the beginning of the $21^{\text {st }}$ Century, China has initiated actions to reform the judicial system so as to promote the professionalism of judicial personnel. Now China is carrying out the reform on judge quota system in an all-round way. Reforming the judge selection and appointment system is a critical step in China's long march toward the rule of law. In order to improve the system of judge selection, on 13 May 2016, the Organization Department of the Central Committee of Communist Party of China, the Supreme People's Court and the Supreme People's Procuratorate jointly promulgated the Opinion on Establishing the System of the Selection of Judges and Public Prosecutors Level by Level, which expressly provides that the judges of the people's courts at the prefecture level or above shall be selected level by level, and a court at a higher level may appoint judges on a selective basis from the courts at the first or second level below it. It is in no doubt that this Opinion marks China's reform on judge selection and appointment system.

It is noted that deciding cases is the primary function of modern judicial system which is characterized by the constitution and operation of judicial bodies. Nevertheless, the judges are the final parties who are undertaking to exercise judicial power on behalf of judicial bodies. Therefore, professionalization of judicial personnel is a vital part of China's judicial reform, which includes a series of issues such as how to select, train, appraise and manage judicial personnel. Given the process of professionalizing judges, whether the design of the regime regarding the entrance, selection and training ${ }^{1}$ of judges is scientific directly concerns whether a sound judicial group has formed on the basis of modern legal profession. In terms of global judicial practice, most developed countries have established mature systems of judge selection and generated relatively rational system models. As for China, the implementation of China's national bar exam marks the start of China's efforts to initiate the process of judicial professionalization. How to learn from other countries' experience in judge selection and how to establish an appropriate system of China's judge selection are salient topics for China's judicial reform.

This paper concentrates on the issue of China's judge selection and is

\footnotetext{
${ }^{1}$ People usually have two types of understandings of judicial training. One refers to the training of the judges who have serve as judges, which is called in-service training. While the other one refers to the training of the candidates who will become judges, which is called pre-service training. See ZHIMING ZHANG, THE MARKS OF JURISPRUdeNTIAL THINKING 341 (China University of Political Science and Law Press 2003). In this paper, judicial training refers to the second type of training which is preservice training.
} 
divided into three parts. Part I describes current situation of China's judge selection, which will provide the materials for the following analysis. Part II examines the system of China's judge selection and indicates the problems thereof. Part III offers suggestions for the reform on China's judge selection. At last, the paper provides a conclusion.

\section{CuRrent Situation of ChinA’s Judge Selection}

In order to promote the process of judicial professionalization, China's judicial reform stresses the system construction of judge selection. China is now reforming the system of judge selection by establishing the criteria for career entrance and qualification, as well as emphasizing the procedures of judge selection, the model of appointment and training.

\section{A. The Entrance Exam for Judges}

Before 2001, China had not established an explicit and unified system regarding how to select judges. The Judges Law only stipulates that the persons to be appointed as judges or assistant judges for the first time shall be selected through public examination and strict appraisal, from among the best qualified for the post, and in accordance with the standards of having both ability and political integrity. ${ }^{2}$ In June 2001, the Standing Committee of National People's Congress promulgated the Decision on Amending Judges Law and Prosecutors Law, which expressly proposed that the persons to be appointed as judges or prosecutors should pass China's national bar exam. ${ }^{3}$ In July 2001, the Ministry of Justice, the Supreme People's Court and the Supreme People's Procuratorate jointly promulgated the Announcement on Several Issues Regarding Implementation of a Unified Bar Exam, which confirms the importance of the bar exam as the entrance exam for the persons who will be appointed as judges. ${ }^{4}$ In December 2001, the Standing Committee of National People's Congress issued the Decision on Amending Lawyers Law, which stipulates that the state institutes a

\footnotetext{
${ }^{2}$ Article 12 of the Judges Law of the People's Republic of China (1995).

${ }^{3}$ See XINHUA NEws, The Ninth Standing Committee of People's Congress Promulgated the Decision on Amending Judges Law and Prosecutors Law, available at http://www.china.com.cn/zhuanti2005/txt/2001-07/01/content_5042145.htm (last visited on 20 March 2017).

${ }^{4}$ The text of the Announcement on Several Issues Regarding Implementation of a Unified Bar Exam, available at http://www.hflib.gov.cn/law/law/falvfagui2/xzf/flfg/WH\%20TY/1006.htm (last visited on 1 March 2017).
} 
system of uniform national bar exam for the qualification of lawyers. ${ }^{5}$ So far, China has established the legal system of a uniform national bar exam.

As far as the nature of China's national bar exam is concerned, Article 2 of the Measures for the Implementation of National Bar Examination (for Trial Implementation) provides that "the national bar exam is a qualification examination uniformly organized by the State for those who wish to be engaged in a certain legal profession; Anyone who is to be a judge or public procurator for the first time or who is to obtain a lawyer qualification certificate must first of all pass the State judicial examination."6 Therefore, the national bar exam is a kind of qualification exam for legal professions and all the people engaged in law should pass the bar exam before hand. ${ }^{7}$ Thus the bar exam is also the entrance exam for judges. It is noted that after more than ten years' implementation of the national bar exam, the General Office of the CPC Central Committee and the General Office of the State Council jointly issued the Opinions on the Improvement of the National Unified Legal Professions Credentialing System in December 2015, which transforms the bar exam into the national uniform qualification exam for legal professions and considers it as the basis for the selection of highquality legal talents. ${ }^{8}$ Now China is promoting the reform on the bar exam and such reform will definitely propel the professionalization of China's judicial personnel.

\section{B. The Qualification and Selection of Judges}

Article 9 of China's Lawyers Law, entitled "Qualifications for Judges", explicitly stipulates the qualifications that judges should satisfy. In addition to the requirement of political and physical qualifications, judges should

\footnotetext{
${ }^{5}$ See Article 6 of the LAWYERS LAW, the text of which is available at http://www.fdi.gov.cn/1800000121_23_67571_0_7.html (last visited on 1 March 2017).

${ }^{6}$ The text of the Measures for the Implementation of National Bar Examination (for Trial Implementation), available at http://www.china.com.cn/chinese/2001/Nov/71735.htm (last visited on 1 March 2017).

${ }^{7}$ It should be noted that judicial professionalization and democratization are not in contradiction with judicial popularization. On one hand, in order to implement the principle of democracy and avoid the shortcomings arising from judicial professionalization, it is common for the states to ask ordinary people to engage in adjudication, which is the jury system. On the other hand, considering the diversity of the cultures in different areas, it is unavoidable that judicial popularization should occur in some areas or at some levels of adjudication. Nevertheless, judicial professionalization is a vital part of China's construction of judicial system and professional judges are the core of the constitution of judicial personnel.

${ }^{8}$ See the Opinions on the Improvement of the National Unified Legal Professions Credentialing System, which is available athttp://www.gov.cn/xinwen/2015-12/20/content_5025966.htm (last visited on 1 March 2017).
} 
also meet the following requirements: "To have worked for at least two years in the case of graduates from law specialties of colleges or universities or from non-law specialties of colleges or universities but possessing the professional knowledge of law; or to have worked for at least one year in the case of Bachelors of Law; those who have Master's Degree of Law or Doctor's Degree of Law may be not subject to the above mentioned requirements for the number of years set for work." "Furthermore, China's Lawyers Law also provides that the persons who have been subjected to criminal punishment for commission of a crime or discharged from public employment cannot hold the posts of judges. ${ }^{10}$ It is therefore concluded that China's Lawyers Law has set out the qualifications for judges from various perspectives which can be divided into the following three aspects: merit, educational history and experience.

Since the national bar exam is only the entrance exam, passing the bar exam does not ensure of the post of a judge. "Persons to be appointed as judges or assistant judges for the first time shall be selected through public examination and strict appraisal, from among the best qualified for the post, and in accordance with the standards of having both ability and political integrity." ${ }^{11}$ As regards the specific procedures and requirements with respect to the appraisal mentioned above, national civil service exam is used to select the persons who will be appointed as judges for the first time given the current practice of China's judicial activities, which means that the persons who want to take the posts of judges must sit for national bar exam first and then pass the national civil service exam and appraisal so as to be appointed as judges according to legal procedures. Judges are now included into the team of civil servants. In June 2014, the Central Leading Team for "Comprehensively Deepening Reform" issued Framework Opinions on Several Issues Regarding the Reform of Judicial Regime (Framework Opinions) and took the initiative to carry out the reform on judge quota system. Pursuant to that Framework Opinions, commissions for the selection of judges and public procurators shall be set up at provincial levels to select judges and public procurators from the professional perspective in order to ensure the capabilities and qualities of the judicial personnel. Given the practice of judge appointment, two major ways of judge appointment, which are "election" and "appointment", are employed in China. According

\footnotetext{
${ }^{9}$ Article 9 of CHINA's LAWYERS LAw, the text is available at http://www.npc.gov.cn/wxzl/gongbao/2000-12/05/content_5004630.htm (last visited on 20 February 2017).

${ }^{10}$ Article 10 of China's Lawyers Law.

${ }^{11}$ Article 12 of ChINA's LAWYERS LAW.
} 
to related laws and regulations, presidents of courts are usually generated by election. The President of the Supreme People's Court is elected by the National People's Congress and the Presidents of local people's courts at various levels are elected by corresponding local people's congresses. Nevertheless, the Presidents of local intermediate people's courts, Vice Presidents of local people's courts at various levels, and the Presidents and Vice Presidents of the tribunals are generated by appointment.

It is worth pointing out that the reform is now broadening the sources of judge selection. The talents from other social sectors may be selected as judges should they satisfy the quality requirement for judges. As early as in the First Five-Year Plan for the People's Courts, the Supreme People's Court proposed to reform the source of judge selection and "to establish the system of selecting outstanding judges from lower courts for higher courts step by step, as well as selecting judges from lawyers and high-level legal experts". ${ }^{12}$ The Second and Third Five-Year Plans for the People's Courts continued to take the means of judge selection as provided in the First FiveYear Plan. For example, in order to improve the cultivation of the newly selected and appointed judges, "the judges of the Supreme People's Court, Higher People's Courts and Intermediate People's Courts shall in principle select or recruit judges from the ones who have relative working experience at the grass-roots level or those who are other brilliant legal talents". ${ }^{13}$ Other brilliant legal talents usually include lawyers, public prosecutors and legal teachers who hold high titles. This measure of reform clarifies the term of "working experience in law" stipulated in previous document regarding judge selection.

\section{C. $\quad$ The Training for Judges}

Current China's Lawyers Law specially provides the system of vocational training for judges, which requires that "theoretical and professional training for judges shall be carried out in a planned way", "the judges colleges and universities of the State and other institutions for training judges shall, in accordance with the relevant regulations, undertake the task of training judges" and "the results of the studies of judges and the appraisals made during their training shall be taken as one of the bases for their appointment and promotion."14 In 2000, the Supreme People's Court issued the Regulation on Vocational Training for Judges and specifies the

\footnotetext{
${ }^{12}$ Article 32 of the Five-Year Plan for the People's Courts.

${ }^{13}$ Article 14 of the Third Five-Year Plan for the PeOPle's Courts.

${ }^{14}$ Articles 26-28 of CHINA's LAWYERS LAW.
} 
details of the training. China's Lawyers Law and the Regulation on Vocational Training for Judges are the major legal basis for the training for judges. While it was noted that before the implementation of the national bar exam, training for judges in China was mainly based on academic education and vocational training was principally for those who were serving the posts of judges. Along with the establishment of professionalization of judicial personnel, especially since the enforcement of uniform national bar exam, China's system of training for judges has been reformed and improved. In 2006, the Supreme People's Court amended the Regulation on Vocational Training for Judges and laid down the system of training for initially appointed judges. Since then, the system of training for initially appointed judges has been established as part of judge selection, and the training for judges on the basis of national bar exam and entrance exam for judges has become an important type of training.

According to the amended Regulation on Vocational Training for Judges (the Regulation), training for judges includes those for initially appointed judges and for the judges in service, for the judges who have just been promoted to a higher position, and for the judges who are appointed again. ${ }^{15}$ Meanwhile, the Regulation also stipulates that the persons who are to be appointed as judges or those who are appointed as presidents for the first time or appointed as vice presidents shall attend the training. ${ }^{16}$ Therefore, according to the subjects who shall undergo training, the training in China is divided into the following two categories: one category of training is for those who are appointed as judges for the first time, which is called initially appointed judges training; the other one is for those who are appointed again, which is called in-service training. The initially appointed judges training in no case shall be less than one year and should focus on post specification, professional ethics, and trial practice experience ${ }^{17}$ From the perspective of current practice and requirement, the initially appointed judges training is divided into the one which shall be held on campus and the other one which shall be held off campus. On campus training includes the training on comprehensive knowledge and vocational skills, and the off campus training is the internship during which the initially appointed judges shall learn and practice at appointed courts, public procuratorates, or other legal service institutions. ${ }^{18}$ The purpose of initially appointed judges training is to equip the judges with necessary trial and legal practice

\footnotetext{
${ }^{15}$ Article 2 of the amended REGULATION ON VOCATIONAL TRAINING FOR JUDGES.

${ }^{16}$ Article 6 of the amended REGULATION ON VOCATIONAL TRAINING FOR JUDGES.

${ }^{17}$ Article 15 of the amended REGULATION ON VOCATIONAL TRAINING FOR JUDGES.

${ }^{18}$ Ibid.
} 
experience so as to enable them to work competently after appointment. By contrast, in service training is aimed to improve the abilities that the judges should acquire to manage and handle cases and shall last not less than one and a half months. ${ }^{19}$ Since China's Lawyers Law provides that the presidents of courts shall be selected from the judges in service, the training for presidents and vice presidents concentrates on the cultivation of the abilities in leadership and profession.

\section{The Problems of ChinA’s Judge Selection}

It is noted that China's judge selection is undergoing the transformation and some critical problems need to be fixed. How to construct a reasonable system of judge selection which will be fundamentally in line with the requirements of modern judicial system and rule of law is a pertinent issue in China's judicial reform. In principle, the following three problems are visible in China's judge selection.

\section{A. Not Fully Respect the Basic Principle of Modern Legal Profession}

It is in no doubt that the systems of judge selection in developed countries have reflected the basic concept of modern legal professionalism, especially from the perspective of the cultivation of qualified judges. To respect the rules and principles of modern legal profession is the core in the construction of modern system of judge selection for the states with modern rule of law. The modern system of judge selection is concerned with various parts and procedures of the cultivation of judges, such as from the admission requirements for initially appointed judges to the series of requirements for assessment and promotion. All those requirements and procedures should present the basic characteristics of modern legal profession.

According to Roscoe Pound, a "profession" is a group of people "pursuing a learned art as a common calling in the spirit of public serviceno less a public service because it may incidentally be a means of livelihood. Pursuit of the learned art in the spirit of a public service is the primary purpose. Gaining a livelihood is incidental, whereas in a business or trade it is the entire purpose" 20 . According to general people's understanding, legal profession in modern society refers to the legal profession community which is composed of the persons who have received professional legal training and are sophisticated in legal knowledge, legal skills and legal

\footnotetext{
${ }^{19}$ Ibid.

${ }^{20}$ Roscoe Pound, The Lawyer for Antiquity to Modern Times 5 (1953).
} 
ethics, with the representatives of judges, public procurators, and lawyers. "The judge profession is a division of legal profession and composed of the professional judges who exercise the function of national adjudication. ${ }^{, 21}$ In essence, judges represent the states to exercise the power of adjudication and play the role of resolvers in handling social disputes. In the states with modern rule of law, reasonable construction and effective operation of judicial system is not separable from the support of highly professionalized judges' community. The fundamental duty of judges is to exercise the power of national adjudication so as to effectively resolve social disputes and ensure the normal order of social life. The purpose of judiciary is to realize fairness and justice in the whole society, which is dependent on the judges' appropriate application of law in the process of adjudications, and thus the professionalization of judges is necessary for the realization of that purpose.

\section{B. Not Comprehensively Manifest the Basic Characteristics of Modern} Judiciary

The professionalization of judges is a constructive element of modern judiciary. Should we compare modern justice to be a skyscraper, the professionalization of judges would be a cornerstone of the skyscraper. The lack of judicial professionalization would result in the loss of judicial independence and justice. ${ }^{22}$ The system of judge selection is a series of system arrangement which is concerned with the qualities and assessment of judges. ${ }^{23}$ Therefore, the system of judge selection which is oriented to the "formation" of qualified judges is the basis for the construction of modern judiciary.

Different from traditional judiciary, modern judiciary stresses judicial specialization and the existence of dedicated staff who are specialized in exercising national judicial power and solving disputes. In other words, the judges should concentrate on the work of adjudication, rather than any other business which has no matter with judiciary. The profession of modern judiciary is reflected in its feature that is the professionalization of judges. The judicial professionalization requires that judges must hold the qualities

\footnotetext{
${ }^{21}$ Mingue Zhang, Judicial Reform-The Review and Outlook of China's Judicial Reform 399 (Social Science Academic Press 2005).

${ }^{22}$ Zhiming Zhang \& Xueyao Li, On Reform of Categorization of Judicial Personnel: Towards Judges' Professionalization, 1 JouRnal of LAW APPLICATION 44 (2007).

${ }^{23}$ Lingzhen Sun \& Lixin Guo, An Overview on the Seminar of the Uniform National Bar Exam, Judge Selection, and the Training for Judges, 1 Journal of National Procurators College 115, 121 (2002).
} 
that are distinctive from common people. Judges should attend specialized legal training and acquire professional legal awareness, knowledge, skills, and practice experience from long-term legal practice. Therefore, when the society becomes more complex, legal rules and regulations will become more abstract and universal, because only in this way can the rules and regulations harmonize the interests and values of different social groups. For the same reason, how to give the advice on dispute settlement and possible manners of dispute resolution becomes more difficult, and the provision of such advice requires specialized training. ${ }^{24}$

China's judicial reform has established the goals and directions of judicial professionalization. To realize judicial modernization is an inevitable trend and the system of China's judge selection should exhibit the basic features of modern judiciary in terms of fundamental thinking and framework. Therefore, the model of judge selection should be anchored in the concept of modern judiciary so as to promote the reform and perfection of China's judge selection. Meanwhile, to learn from overseas successful experience in judge selection is complementary to the establishment of China's judge selection pursuant to judicial modernization.

\section{C. $\quad$ Not Completely Present the Trend of Worldwide Judge Selection}

In contrast to legal professors, judges who are engaged in specialized legal profession of deciding cases should possess specialized knowledge and skills that satisfy the requirements of adjudication work. Therefore, in the context of modern rule of law, although judges may work in different societies and systems, the concepts and criteria that are used to evaluate judges are quite different. ${ }^{25}$ The system of judge selection is related to the method that is used to select judges and the category of people that are selected as judges. From the perspective of general practice of developed countries, to cultivate qualified and competent judges on the basis of judicial modernization is the basic goal of the system of judge selection. As regards reasonable construction of the system of judge selection, although various countries have diversified situations and cultures, something in common that is shared by the countries in terms of judge selection, which is the rule of development. For example, Article 10 of the Basic Principles on the Independence of the Judiciary, which was passed by the UN Crime

\footnotetext{
${ }^{24}$ See H. W. Elhman, Comparative Legal Culture 86 (translated by Weifang He, Tsinghua University Press 2002).

${ }^{25}$ Zhiming Zhang, The Marks OF JuRisprudential Thinking 345 (Chinese University of Political Science \& Law Press 2003).
} 
Congress in 1985, stipulates that "[p]ersons selected for judicial office shall be individuals of integrity and ability with appropriate training or qualifications in law. Any method of judicial selection shall safeguard against judicial appointments for improper motives. In the selection of judges, there shall be no discrimination against a person on the grounds of race, color, sex, religion, political or other opinion, national or social origin, property, birth or status, except that a requirement, that a candidate for judicial office must be a national of the country concerned, shall not be considered discriminatory." ${ }^{26}$ This Article reflects the common sense reached by the people in international legal field regarding the principles of judge selection.

In order to safeguard judicial professionalization, special standards for judges are designed by modern countries and used as the requirements for judges' appointment and promotion. As regards the judges in service, systemic vocational training has been established to cultivate the judges' legal skills. For example, according to German law, the judges must meet the qualification requirement of judicial work and that qualification includes the passing of national judicial exams twice. Before a person acquires the qualification of attending the bar exam, he/she generally should receive legal education from universities and colleges and attend special internship of legal education organized by the judicial departments of each state. At last, the ministers of judicial departments of each state shall select judges from the persons who have performed well during the twice judicial exams. Moreover, the persons initially appointed as judges shall serve as probationary judges for the period of three or five years, and only after that can those judges get lifetime appointments. The countries of common law emphasize legal practice experience of the judges before their appointment. In Britain, except that the magistrates are selected from the persons of nonlegal majors in communities, all other judges at various levels and courts are selected from senior barriers-in-law. In terms of the training after appointment, most countries have something in common, which is to train the judges in service by special institutions set up by the states. In this respect, the German Judicial Academy and the training institutions set up in each state of Germany, the Federal Judicial Center of the United States, and the Legal Training and Research Institute of Japan are all such institutions that provide regular training for judges.

\footnotetext{
${ }^{26}$ See the United Nations, Basic Principles on the Independence of the Judiciary, available at https://www.un.org/ruleoflaw/blog/document/basic-principles-on-the-independence-of-the-judiciary/ (last visited 1 April 2017).
} 


\section{The Advice on ChinA’s Professionalization of Judge Selection}

In addition to insistence on certain concepts and principles from the allround angle, the perfection of China's professionalization of judge selection should make further progress in the construction of reasonable and scientific system. According to the research on theories and practice, the discourse on how to improve the system of judge selection is fruitful and covers almost all the aspects thereof. In addition, some visons and designs on the system of judge selection have been gradually transformed into the reality of China's judicial system following the development of China's judicial reform. ${ }^{27}$ Given the situation of China's system of judge selection, the following four points are worth special attention in order to realize China's judicial professionalization.

\section{A. To Establish a Combined System of Judge Selection}

China's uniform national bar exam plays a significant role in the training for judges. The bar exam contributes to improve the qualities of the whole legal practitioners, establish China's legal profession community, cultivate legal talents, and prevent arbitrariness in the selection of judicial personnel. However, considering the essence of modern legal profession and the requirements on the comprehensive qualities that legal practitioners should hold, China's bar exam should be reformed in terms of candidates' qualification, the model and contents of the exam, and the organization of the exam. It is noted that the Opinions on the Improvement of the National Unified Legal Professions Credentialing System, which was issued in December 2015, stipulates that all the participants taking the national bar exam must receive official and formal legal education. ${ }^{28}$ How to learn from the experience of developed countries in the design of the bar exam, especially from those countries that share similar traditions and cultures with China, is important for the perfection of China's bar exam, as well as for the improvement of China's system of judge selection.

The persons who have passed China's national bar exam obtain the qualification of practicing law, but that does not mean those persons will definitely be appointed as judges. It is naive to expect that the national bar exam alone will meet all the purposes and standards of judge selection. By

\footnotetext{
${ }^{27}$ Lingzhen Sun \& Lixin Guo, An Overview on the Seminar of the Uniform National Bar Exam, Judge Selection, and the Training for Judges, 1 Journal of National Procurators College 115, $122-125$ (2002).

${ }^{28}$ See the Opinions on the Improvement of the National Unified Legal Professions Credentialing System.
} 
contrast, the national bar exam is only part of the system of judge selection. Considering the current situation of China's system, to strengthen the connectivity between the national bar exam and civil service exam that is used to select judges is necessary. Moreover, there is much room to make improvement in perfecting the training system for judges so that the training programs would play a complementary role in the cultivation of qualified judges. Therefore, to establish a combined system that coordinate the national bar exam, civil service exam and the training system for judges is pivotal in terms of professionalization of China's judge selection.

\section{B. To Explore Multiple Ways of Judge Selection}

To select judges from the persons who have passed China's national bar exam is the general practice of China in judge selection. Nevertheless, given overseas multiple ways of judge selection, China should also select judges in different ways so as to fix the shortcomings that are revealed from China's judge selection which is to a large extent dependent on the national bar exam. To explore multiple ways of judge selection is beneficial for China and the following four ways should be taken into account: First, train the persons who have passed the national bar exam for a relatively long period and then select judges from those attending the training; second, select judges from outstanding lawyers who are full of experience in legal practice and the passion to work as judges; third, select judges from the professors and legal researchers who have distinctive achievements in law; fourth, appoint judges from those who have passed strict and comprehensive assessment on their legal awareness, knowledge, skills, and ethics. The final way of judge selection is particularly suitable for the areas which are underdeveloped and lack legal talents. ${ }^{29}$

In addition, competition should be introduced to the system of judge selection, especially for the selection of judges from lower positions to higher positions. Shanghai is a case in point. Shanghai has implemented the competitive promotion system in its all-city promotion recruitment competitions since 2008. ${ }^{30}$ The Shanghai competitive promotion system works as follows: candidates for promotion to mid-level judicial positions in Shanghai's Intermediate Courts or above must attend the competitive promotion process; vacancies in the Shanghai Courts are open to all the

\footnotetext{
${ }^{29}$ Jianzong Yao, The National Uniform Bar Exam and China's Selection of Judges: Basic Observations and Framework Design, 2 LAW AND SOCIAL DEVELOPMENT 3, 7 (2002).

${ }^{30}$ See Jonathan J. Kinkel, High-End Demand: The Legal Profession as a Source of Judicial Selection Reform in Urban China, 40(1) LAW \& SOCIAL INQUIRY 969, 988 (2015).
} 
qualifying judges who work in Shanghai; The judges working in the Subordinate Courts are qualified to compete for the vacancies in the Shanghai Intermediate Court and High Court as senior as the High Court department vice-chief. ${ }^{31}$ The all-city competitive promotion system used in Shanghai injects vitality into the Shanghai judicial personnel. For example, in 2010, 106 applicants from courts across Shanghai applied for five vacancies at the Intermediate and High Court levels. ${ }^{32}$ Shanghai not only substantively implements the competitive promotion system, but also uses the system routinely. Each time when there is a vacancy for a mid-level judicial position, the competitive promotion system will be employed. Moreover, the competitive promotion system has also been streamlined so that the candidates applying for the vacancies do not have to present speeches in front of the whole court describing why they are competent for the positions. ${ }^{33}$

By contrast, Shenzhen also implements the competitive promotion system but only uses it at the within-court level, which means that the vacancies in a court are not open to the qualifying judges who do not work in that court. ${ }^{34}$ Chengdu also uses the competitive promotion system at the within-court level, but not uses it routinely. ${ }^{35}$ It is evident that Shanghai competitive promotion system is most effective, open-minded, and meritbased. Chengdu competitive promotion system is arbitrary and outmoded. While Shenzhen competitive promotion system falls between Shanghai and Chengdu. ${ }^{36}$ Therefore, the conclusion is reached that cities in China may adopt the same competitive promotion system in name, but the substance and essence of the systems are quite different.

Due to the diversity and broadness of Chinese territory, different places may explore the way of judge selection that is most suitable for their situations. Multiple ways of judge selection should be explored in order to inject the energy and vitality to the system of judge selection. However,

\footnotetext{
${ }^{31}$ See Jonathan J. Kinkel, High-End Demand: The Legal Profession as a Source of Judicial Selection Reform in Urban China, 40(1) LAW \& SOCIAL INQUIRY 969, 988 - 989 (2015).

${ }^{32}$ See Jonathan J. Kinkel, High-End Demand: The Legal Profession as a Source of Judicial Selection Reform in Urban China, 40(1) LAW \& SOCIAL INQUIRY 969, 989 (2015).

${ }^{33}$ It is well believed in China that candidate speeches are repetitive exercises that suffice little new information and waste valuable work time. See Jonathan J. Kinkel, High-End Demand: The Legal Profession as a Source of Judicial Selection Reform in Urban China, 40(1) LAW \& SOCIAL INQUIRY 969, 989 (2015).

${ }^{34}$ See Jonathan J. Kinkel, High-End Demand: The Legal Profession as a Source of Judicial Selection Reform in Urban China, 40(1) LAW \& SOCIAL INQUIRY 969, 989 (2015).

${ }^{35}$ See Jonathan J. Kinkel, High-End Demand: The Legal Profession as a Source of Judicial Selection Reform in Urban China, 40(1) LAW \& SOCIAL INQUIRY 969, 990 (2015).

${ }^{36}$ See Jonathan J. Kinkel, High-End Demand: The Legal Profession as a Source of Judicial Selection Reform in Urban China, 40(1) LAW \& SOCIAL INQUIRY 969, 991 (2015).
} 
competition, transparency, and efficiency are the key factors that should be taken into account no matter which way of judge selection is adopted.

\section{To Build a Comprehensive Training System}

There are two models of training on the basis of China's national bar exam: One is to select judges and public procurators from the persons who have passed the bar exam and then train those selected persons separately pursuant to their appointed posts. It means that initially appointed judges and public procurators will receive different types of training before they assume their posts. Candidate lawyers, who have passed the bar exam, may accordingly attend the training for lawyers. That arrangement is called "unified exam and separate training". The other model is to train uniformly all the persons who have passed the bar exam no matter what posts they may assume thereafter, and then select judges, public procurators and lawyers from those who have successfully attended training and performed well during the training. This arrangement is called "unified exam and unified training". China is now adopting the first model to operate its legal training system. It is not disputable that the two models have different functions and either model has its own advantages. From the perspective of the cultivation of China's legal profession community, China does not have any system that promotes the formation of legal profession community in addition to the national bar exam. That situation is reflected in the legal education provided by Chinese universities, which is not professional education as that provided by the countries such as the United States. In addition, China lacks traditional culture of legal profession, which may damage the original value orientation of the national bar exam. Thus in the long run, China should learn from other countries' legal training, especially the practice of civil law countries, and actively build a unified system of legal training so as to realize harmonious development among all the persons including judges, public procurators and lawyers, who are working in law.

No matter which model of training is adopted, attention should be paid to the substance of the training, as well as the languages that are used during the training. As regards the substance, the primary thing is to select appropriate and outstanding persons to serve as trainers. In China, professors and scholars may hold the posts of trainers and teach legal theories to the judges. It is undeniable that professors and scholars are highlevel and full of legal knowledge. Nevertheless, disputes that occur in real life may be thorny and quite different from the legal theories that are 
familiar to the professors and scholars. Deep and abstract legal theories may not be helpful for the resolution of disputes. China should learn from the experience of the United States and select the trainers from prestigious judges ${ }^{37}$ because judges know judges and know what judges are dealing with every day. In addition, the methods of training should also be improved. China's training for judges traditionally focuses on teaching, which is similar with the way of teaching in the universities and colleges. In fact, other teaching methods such as interaction, debate, and interrogation should also be employed to enrich the training.

As regards the languages that are used during the training, it is noted that China has 55 ethnic minority groups. To respect the right of the ethnic minority groups to use their own languages is a fundamental national policy of China. ${ }^{38}$ Therefore, the training for the judges working at the ethnic minority areas should be implemented with both languages of mandarin and the ethnic minority language which is dependent on the ethnic minority area. In 2015, the Supreme People's Court issued the Opinion on Further Strengthening and Improving Bilingual Cultivation and Training for Judges, which emphasizes the cultivation of the judges who are sophisticated in mandarin and the ethnic minority group's language. ${ }^{39}$ Thus the languages used during the training for the judges who work in ethnic minority areas should be different from those who work in other areas. To ensure that the judges of ethnic minority areas can fluently speak bilingual languages will facilitate the resolution of disputes that is involved with the party of ethnic minority groups. ${ }^{40}$

\section{To Promote the Reform on the Formation of Judicial Personnel}

Following the construction and reform of China's trial system, more and more emphasis has been placed on the "element of persons" and professionalization of judicial personnel has become an indispensable part in China's judicial reform. The concept that the perfection of China's judicial personnel and judge system should be based on judicial

\footnotetext{
${ }^{37}$ Ying Li, The Reference of the United States Judge Training for China, 8 LAW APPLICATION 46, 48 (2000).

${ }^{38}$ See the document The State Ensures the Ethnic Minority Groups' Rights to Use and Develop Their Own Languages, available at http://www.seac.gov.cn/art/2012/5/31/art_5568_156239.html (last visited on 1 February 2017).

${ }^{39}$ Paragraph 8 of the Opinion on Further Strengthening and Improving Bilingual Cultivation and Training for Judges, available at http://www.court.gov.cn/zixun-xiangqing-17442.html (last visited on 1 February 2017).

${ }^{40}$ See Yongjian Zhang, Jointly Promote Bilingual Training for the Judges of Ethnic Minority Groups, People's Court Daily 3 September 2016.
} 
professionalization has been proven sound and scientific, and thus judicial professionalization has become a pivotal issue in China's construction of trial system.

Similar with the construction and reform on other aspects of China's trial system, the construction and reform on the formation of China's judicial personnel is a long and complicated project. Especially considering the historical influence and the current situation of China's trial activities, various difficulties are in front of the realization of China's judicial professionalization. Although the Chinese judicial academic and practical circles have proposed a series of reform measures before the issue of judicial professionalization was raised, how to delineate a road to propel the reform on China's judicial professionalization is a significant issue in China's complex judicial scenario. For example, scholars have suggested taking following measures to promote China's judicial professionalization: (1) To reform the current system of judge selection and appointment and to improve the various parts of judge system, including the selection, cultivation, assessment and promotion procedures so as to keep the most outstanding legal talents in courts; (2) to establish the system that is suitable for the regulation of different types of judicial personnel and rationalize the relationship among the judges and other judicial personnel such as supporting staff and logisticians; (3) to improve the case flow management system and reduce the judges' work that is not related to trial so as to enhance the effective handling of cases; (4) to build the system in which presiding judges are mainly responsible for the trial of cases so that the judges of sophisticated legal knowledge and skills will become the backbone of judicial personnel. ${ }^{41}$ In the fields of judicial practice, the Supreme People's Court in Several Opinions on Strengthening the Professionalization of Judicial Corps proposed to establish strict entrance system for judges, improve judges' professional awareness, cultivate judges' professional ethics, promote judges' professional skills and images, safeguard the security of judges' profession and perfect the supervisory system for judges. ${ }^{42}$ Therefore, how to push forward the reform on the

\footnotetext{
${ }^{41}$ See Chenguang Wang, The Professionalization and Specialization of Judges and Related Limitations in JudicIAL REFORM - THE REVIEW AND OUtLOOK OF CHINA's Judicial REFORM 381382 (Mingjie Wang (ed.), Social Science Academic Press, 2005); Chenguang Wang, The Efficiency of Case Handling and the Reform of Internal Court System-An Unavoidable Aspect in the Reform of Trial Manner, (10) Legal SCIENCE (1998); Jing He, The System of Selecting Presiding Judges Will Promote the Progress of Judicial Professionalization, People's Court DAILY (31 May 2001).

${ }^{42}$ Supreme People's Court, Several Opinions on Strengthening the Professionalization of the Judicial Corps, available at https://chinacommission.gov/pages/newLaws/judgeCorpsStrength.php (last visited 1 April 2017).
} 
formation of China's judicial personnel with consideration of China's social situation and thus design an appropriate reform framework is a pertinent issue in China's judicial professionalization.

With the promotion of China's judicial reform, the judicial professionalization in China is inevitably confronting the problems that exist in China's judiciary. Therefore, how to delineate those problems and find out an appropriate route to realize judicial professionalization is a salient topic. Given the general framework and comprehensive design of judicial professionalization, attention should be paid to the nature of the constitutive structure of judicial personnel. China has adopted aseparate management approach to different types of judicial personnel, which is to identify the judge corps, sort out different responsibilities for different judicial personnel, and assess those personnel's work according to their different responsibilities so as to promote the construction of judicial professionalization.

According to the documents issued by the Supreme People's Court, China has been mature in employing the separate management approach to administer judicial personnel since the circulation of the Second Five-Year Plan for the People's Courts. The Second Five-Year Plan stipulates that "[p]romote the separate management for different types of judicial personnel. Formulate management systems for judges, judicial clerks, secretaries, enforcement personnel, judicial police, judicial administrative personnel, judicial technical personnel, and others. Strengthen the professionalization of judges and other personnel. Construct judicial job responsibilities in accordance with trial work and the nature of judicial work. Use prior experience to steadily construct a system of judicial clerks."43 Since then, China has specified the reform direction regarding separate management for different types of judicial personnel, which is anchored in judicial professionalization. The Third Five-Year Plan for the People's Courts continues to stress the construction of judicial personnel and states that "to improve the separate management for judges and support staff." 44 Until now, the reform on the constitution of judicial personnel has become one route to realize the reform on judicial professionalization.

Given the existing regulation and reform practice, the reform on separate management for judicial personnel is oriented to follow the direction of reform on judicial professionalization and separate the judges from other judicial staff who are not engaged in trial work. Considering the

\footnotetext{
${ }^{43}$ Paragraph 34 of the SECond Five-Year Plan For the People's Courts.

${ }^{44}$ See Paragraph 19 of the ThiRd Five-YeAr Plan FOR THE PEOPLE's CourTs, available at http://www.court.gov.cn/shenpan-xiangqing-323.html (last visited on 1 February 2017).
} 
nature of trial work, to promote the professionalization of the judges who are responsible for trial work by separate management for judges and other staff is meaningful to improve the qualities of the judges' work. It is not exaggerated to conclude that the separate management system is a precondition to promote the reform on judicial professionalization.

\section{CONCLUSION}

The system of judge selection is part of a state's judicial system. Whether the design of the system of judge selection is scientific and reasonable and whether the system operates smoothly directly affect the qualities of the judges, as well as influencing a state's operation of judicial power. ${ }^{45}$ China's professionalization of judge selection system, which includes the items of the uniform national bar exam, judge selection and legal training, carries on the task of selecting qualified judges for China and takes up a key position in China's judicial reform. In other words, "judicial professionalization" is a kind of reflection on China's construction of rule of law and judicial reform, and reveals the transformation of China's concept from the emphasis on the element of "rules" to the stress on the importance of "persons". ${ }^{46}$ Under the guidance of judicial professionalization, to make further progress in rationalization and perfection of China's system of judge selection, which will substantively ensure the adequacy and quality of China's judicial personnel, is still a goal that should be insisted on in China's judicial reform. Specifically, four pieces of advice on China's professionalization of judge selection are proposed, which are to establish a combined system of judge selection, to explore multiple ways of judge selection, to build a comprehensive training system, and to promote the reform on the formation of judicial personnel.

\footnotetext{
${ }^{45}$ Shigui Tan, Studies on Chinese Judiciary 60 (Law Press China 2009).

${ }^{46}$ Zhiming ZhANG, The Marks OF JURISPRUdENTIAL ThinkING 361 (China University of Political Science and Law Press 2003).
} 